\title{
ORGANISASI KOMPUTER VESA(VIDEO ELECTRONICS STANDARDS ASSOCIATION) LOCAL BUS
}

\author{
Oleh: Irma T. \\ Prodi Pendidikan Matematika Jurusan Tarbiyah STAIN Palopo
}

\begin{abstract}
Abstrak:
Vesa (Video Electronics Standards Association) Local Bus merupakan jalur yang dibuat untuk menyesuaikan kecepatan mikroprosesor di dalam komputer. Vesa local bus dibuat oleh Video Electronics Standards Association yang banyak digunakan pada personal computers berbasis Intel 80486 CPU,Vesa local bus berdampingan dengan Isa Slot. Dalam artikel ini akan di tunjukkan bagaimana kemampuan transfer data, apakah bisa mencapai kecepatan maksimum 66 Mhz dengan lebar 64 bit. Dari kajian yang dilakukan terlihat bahwa kemampuan transfer data sebanyak $528 \mathrm{Mb} / \mathrm{s}$ dari clock speed $66 \mathrm{Mhz}$ dan lebar bit 64 tidak dapat direalisasikan karena hanya dapat bekerja pada clock speed $33 \mathrm{Mhz}$ dan lebar bit 32 hingga transfer data hanya $132 \mathrm{Mb} / \mathrm{s}$.
\end{abstract}

Kata kunci: Vesa Local Bus

\section{Pendahuluan}

Bus merupakan media transmisi yang dapat digunakan bersama. Sistem komputer terdiri dari sejumlah bus yang berlainan menyediakan jalan antara dua buah komponen pada bermacam-macam tingkatan hirarki sistem komputer. Vesa (Video Electronics Standards Association) Local Bus merupakan jalur yang dibuat untuk menyesuaikan kecepatan mikroprosesor di dalam komputer.

Vesa local bus dibuat oleh Video Electronics Standards Association yang banyak digunakan pada personal computers berbasis Intel 80486 CPU,Vesa local bus berdampingan dengan Isa Slot. Vesa local bus juga disebut VL-Bus atau lebih singkatnya VLB diperkenalkan pada tahun 1992. Alasan utama pengembangan VLB ini untuk meningkatkan kemampuan video pada personal komputer. Vesa local bus ini menjadi populer antara tahun 1993 hingga 1994 pada mesin prosesor berbasis 486 


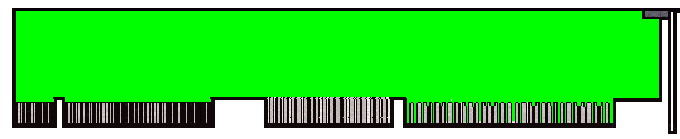

VESA - LOCAL BUS

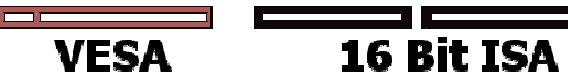

Gambar 1. Kartu Vesa

Dalam artikel ini, akan di tunjukkan bagaimana kemampuan transfer data, apakah bisa mencapai kecepatan maksimum 66 Mhz dengan lebar 64 bit?

\section{Pembahasan}

Vesa local bus yang didesain hanya pada mesin prosesor 80486 mempunyai spesifikasi data teknis sebagai berikut

$>$ Didesain untuk kebutuhan Intel 486 processor

$>$ Transfer data $: 132 \mathrm{MB} / \mathrm{sec}$

$>$ Panjang : 4 Inchi Lebih Panjang Dari Slot Isa

$>$ Kecepatan normal $: 33 \mathrm{MHz}$

$>$ Kecepatan Maksimal : $: 66 \mathrm{MHz}$

$>$ VLB cards menggunakan maksimal 32-bit bus

> VL Bus versi 2.0 mengijinkan 3 slot $40 \mathrm{MHz}$ dan 2 Slot $50 \mathrm{Mhz}$ jika kapasitas rendah dijaga

$>\mathrm{VL}$ Bus versi 2.0 menggambarkan 64 bit dimana kecepatan transfer mencapai $400 \mathrm{MHz} / \mathrm{Sec}$

$>$ VL Bus hanya cocok pada mesin 486 karena mempunyai masalah dengan kecepatan $66 \mathrm{Mhz}$

Operasi dari bus VLB pada pada bus di sistem komputer yang berisi signal-signal dari cpu akan dijelaskan sebagai berikut :

$>$ Cpu mengirimkan signal ke $\mathrm{l} / \mathrm{O}$ controller sehingga dapat menangani operasi VI Bus

$>\mathrm{I} / \mathrm{O}$ controller memecahkan kode alamat untuk menetapkan jika signal adalah untuk beberapa local-bus adapters

$>$ Signal akan ke non-local bus adapters dikirim untuk ISA I/O controller,sementara signal yang dilewati oleh $33 \mathrm{MHz}$ and 32bits, ISA controller akan mengconvert signal itu menjadi 16 bit, $8 \mathrm{MHz}$ untuk ISA BUS.

$>$ Jika sebuah signal adalah untuk VESA Local Bus maka Vesa Controller akan mengirimkan sebuah signal ke 
87 | al-Khwarizmi, Volume II, Edisi I, Maret 2014, Hal. 85 - 90

adapter dalam slot dan kemudian menanyakan apakah adapter akan mengeksekusi permintaan operasi tersebut

> Pertama kali adapter memulai operasi, $V L$ controller membiarkan data untuk beroperasi langsung dari prosesor ke local bus slot melewati 32 bit data dan melampaui kecepatan diatas $50 \mathrm{MHz}$

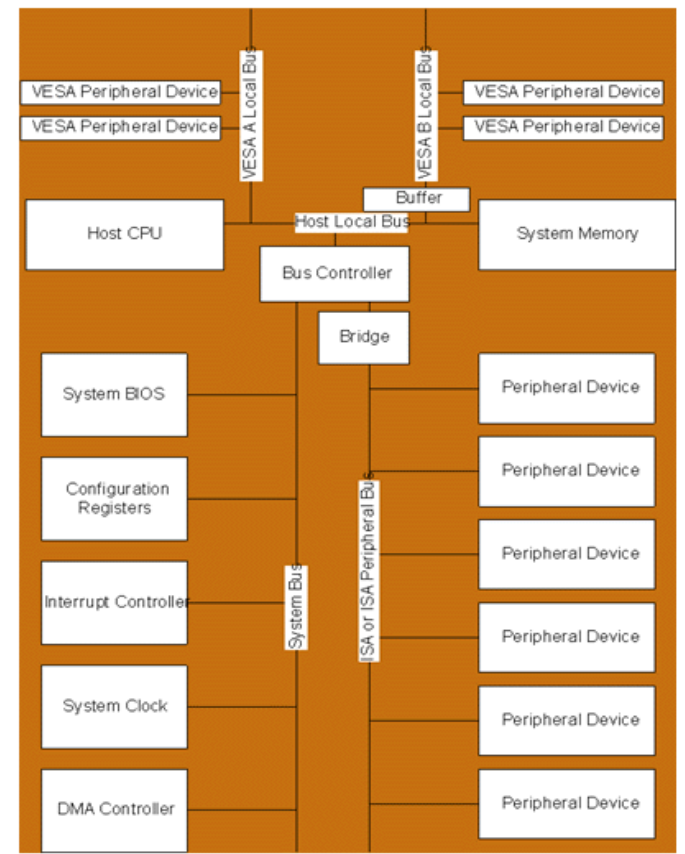

Gambar 2. Bagan Bus

Vesa local bus menjadi populer pada antara tahun 1993 hingga 1994 karena beberapa feature yang ditawarkan oleh VLB kemampuan dari VLB sebagai berikut:

> VLB dibuat untuk menangani ketidakmampuan Isa Bus dalam mentransfer data yang cukup cepat

$>$ VLB didesain untuk menangani dan mengijinkan perangkat yang mempunyai volume besar seperti hardisk untuk digunakan dalam bus

> Untuk Burst mode, transfer data $33 \mathrm{Mhz}$ pada 32-bit adalah $132 \mathrm{MB} / \mathrm{Sec}$ : pada transfer data Bus menggunakan single address cycle yang diikuti oleh 4 data cycle yang berarti memerlukan 5 clock cycle untuk mentransfer masing-masing 4 double-words 32- 
bits,sehingga $4 \times 32$ bits (128bits) masing-masing 5 clock cycles yang mana kecepatan riil nya $105 \mathrm{MB} / \mathrm{s}$

untuk non-burst mode menggunakan transfer data 66 $\mathrm{MHz}$ yang mana meminta sebuah address cycle untuk tiap transfer 32 bit sehingga memerlukan 2 clock cycle

$>$ Pengolahan data yang cepat karena 'perlombaan' dengan kartu yang lebih lambat sudah dihilangkan

> Akses yang lebih cepat karena vesa local bus bekerja pada kecepatan processor dibandingkan dengan main expansion bus

$>$ Akses langsung ke processor bus

$>$ Akses langsung ke sistem memori dengan kecepatan processor itu sendiri

$>$ Kemampuan transfer 32 bit

$>$ Perbedaan fisik slot sehingga mencegah kartu yang lambat ditancapkan pada slot yang cepat

Disamping kemampuan dari vesa local bus terdapat keterbatasan dari vesa itu sendiri hingga dikembangkan pada PCl pada tahun 1994 keterbatasan pada local bus seabagai berikut:

$>$ Tersedia hanya untuk digunakan pada processor 486

$>$ Tidak dikembangkan untuk kecepatan pentium

> Kecepatan maksimum 66 Mhz tapi kenyataannya terbatas pada kecepatan $33 \mathrm{Mhz}$

- Maksimum 3 kartu tergantung sumber daya sistem

$>$ Sangat buruk untuk implementasi bus mastering

$>$ Tidak mendukung plug and play

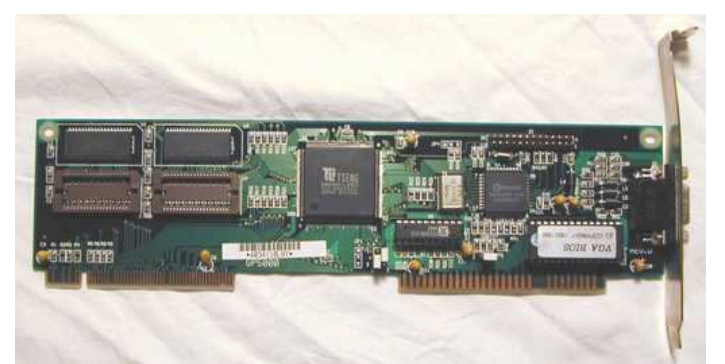

Gambar 3. Card VESA bus

Gambar 4. Vesa Slot 
89 | al-Khwarizmi, Volume II, Edisi I, Maret 2014, Hal. 85 - 90
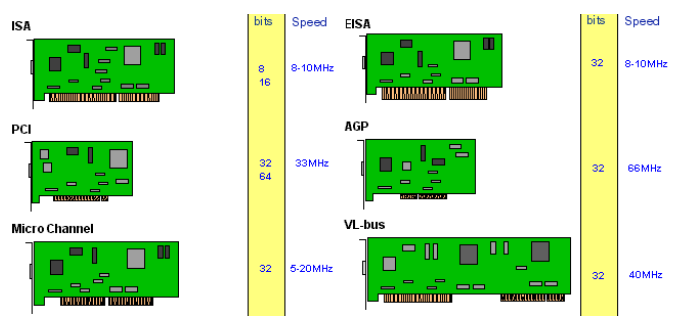

Gambar 5. Card - Card Isa hingga VI-Bus

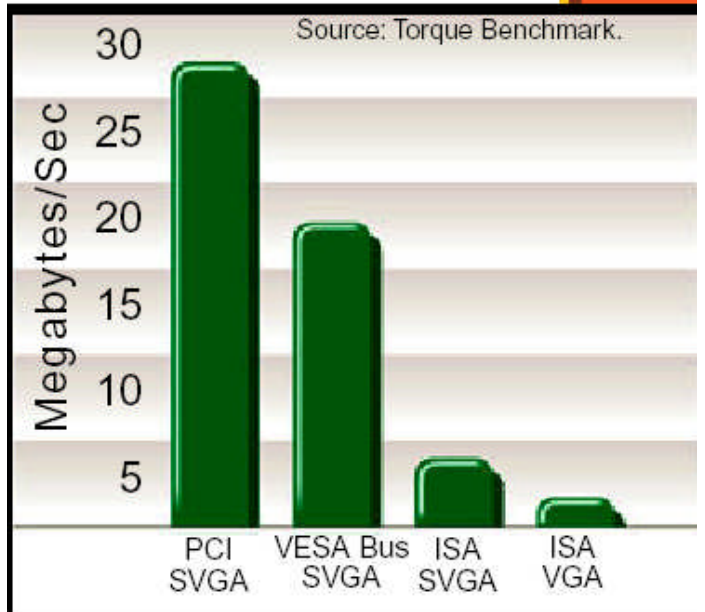

Gambar 6. Gambaran Peningkatan Transfer Rate Video

Mainboad yang menggunakan Vesa $L B$ misalnya MB54VP Pentium Motherboard:

$>$ BIOS ID string

$>$ 4-72 pin simm slots (128meg fpm dram)

$>$ 4-32bit pci slots

$>$ 2-32bit vesa slots

$>$ 5-16bit isa slots

$>$ 256k-1024k cache support in 8-32pin sockets +1 tag ram socket

$>$ award 1994 auto-detect with energy mgmt.

$>$ supports lba mode control \& large disk dos compatibility.

$>$ opti chipset <--- confirm chipsetversion

$>$ 320pin pentium zif socket 5 which supports these

> Processors: intel pentium 75/90/100 mhz 


\section{Kesimpulan}

Kemampuan transfer data sebanyak $528 \mathrm{Mb} / \mathrm{s}$ dari clock speed 66 Mhz dan lebar bit 64 tidak dapat direalisasikan karena hanya dapat bekerja pada clock speed $33 \mathrm{Mhz}$ dan lebar bit 32 hingga transfer data hanya $132 \mathrm{Mb} / \mathrm{s}$.

\section{DAFTAR PUSTAKA}

http://en.wikipedia.org

http://www.adaptec.com/technology

http://www.hardwarecentral.com

http://www.hardwaregrundlagen.de

http://www.indiana.edu

http://www.microstar.net

http://www.nationmaster.com

http://www.pccomputernotes.com

http://www.pcguide.com

http://www.tonh.net 